\title{
A Structural Equation Modelling Evaluation of Antecedents and Interconnections of Call Centre Agents' Intention to Quit ${ }^{\dagger}$
}

\author{
Chux Gervase Iwu ${ }^{1, *} \mathbb{D}$, Abdullah Promise Opute ${ }^{2}$, Olayemi Abdullateef Aliyu ${ }^{3}$, Chukuakadibia Eresia-Eke ${ }^{4} \mathbb{D}_{\text {, }}$ \\ Tichaona Buzy Musikavanhu ${ }^{5}$ and Afeez Olalekan Jaiyeola ${ }^{1}$ (D)
}

1 Faculty of Business and Management Sciences, Cape Peninsula University of Technology, Cape Town 8000, South Africa; adesanya56@gmail.com

2 Department of Research, Academic and Management Consultancy, GPROM Academic and Management Solutions, 33154 Salzkotten, Germany; promise.opute@gpromsolutions.org

3 Faculty of Business Management and Legal Studies, Toi Ohomai Institute of Technology, Rotorua 3046, New Zealand; Aliyu.Abdullateef@toiohomai.ac.nz

4 Faculty of Economic and Management Sciences, University of Pretoria, Pretoria 0002, South Africa; chuks.eresia-eke@up.ac.za

5 Faculty of Commerce, Boston City College, Cape Town 7600, South Africa; tichbuzy@gmail.com

* Correspondence: iwuc@cput.ac.za

† In Memoriam: Dr. Afeez Olalekan Jaiyeola (born 4 January 1980, died 31 January 2021)

check for updates

Citation: Iwu, Chux Gervase, Abdullah Promise Opute, Olayemi Abdullateef Aliyu, Chukuakadibia Eresia-Eke, Tichaona Buzy Musikavanhu, and Afeez Olalekan Jaiyeola. 2021. A Structural Equation Modelling Evaluation of Antecedents and Interconnections of Call Centre Agents' Intention to Quit . Journal of Risk and Financial Management 14: 179. https://doi.org/10.3390/ jrfm14040179

Academic Editor: Michael McAleer

Received: 1 March 2021

Accepted: 8 April 2021

Published: 13 April 2021

Publisher's Note: MDPI stays neutral with regard to jurisdictional claims in published maps and institutional affiliations.

Copyright: (C) 2021 by the authors Licensee MDPI, Basel, Switzerland. This article is an open access article distributed under the terms and conditions of the Creative Commons Attribution (CC BY) license (https:/ / creativecommons.org/licenses/by/ $4.0 /)$.

\begin{abstract}
Call centers play a significant role in the operational dynamics of different types of businesses. This is especially the case because a call center agent's demeanor can impair or engender customer satisfaction, which has ramifications for business patronage. Unfortunately, the pressures associated with the role of the call center agent have made staff attrition a norm in the industry. While this does not augur well for the call center or the organizations that they serve, the role of possible antecedents in the equation of staff attrition in South African call centers remains largely unexplored. Using a structural equation modeling approach, this study examined the interconnections between customer orientation, knowledge management, job satisfaction, and employees intention to quit. Additionally, the mediating influence of job satisfaction on the association between customer orientation and knowledge management of the intention to quit is examined. This study found significant relationships between knowledge management, customer orientation, and job satisfaction and the dependent variable (intention to quit). In addition, this study establishes that the extent to which job satisfaction may mediate the influence on the intention to quit hinges on the organizational element considered. Two factors limit the extent to which the findings from this study can be generalized. First, this study focused on the call center setting in South Africa. Second, convenience sampling was used in this study. This study points to critical operational practices that call center managers can embrace toward enhancing job satisfaction and reducing intention to quit propensity. Using structural equation analysis, we contend that call centers in the South African setting would effectively address staff attrition if appropriate organizational practices are endorsed toward ensuring employee job satisfaction.
\end{abstract}

Keywords: customer orientation; knowledge management; job satisfaction; employee turnover; intention to quit; call center; risk management

\section{Introduction}

Call centers have become the norm for organizations wishing to remain in close contact with their customers. Interestingly, while call centers ought to offer competitive intelligence to firms, they have to contend with high levels of absenteeism and staff attrition, as is often the case with call centers in South Africa (Poon and Dyantyi 2004; Dhanpat et al. 2018; Zurnamer 2019). Research has distilled the dual consequences of high employee turnover for organizations: unrecouped financial investments (Bilau et al. 2015; 
Cohen and Veled-Hecht 2010; Ibrahim 2015) and indirect financial resources such as the loss of valuable knowledge (Mwilu 2016).

Employee turnover could take a voluntary or involuntary form. While voluntary turnover refers to situations where employees decide to resign by themselves, involuntary turnover arises when organizations terminate or dismiss employees (De Winne et al. 2018). Additionally, turnover can be dysfunctional or functional. Dysfunctional turnover occurs when star employees of organizations are laid off and functional turnover manifests when organizations encourage all employees, especially the poorly performing employees, to leave (Becton et al. 2017).

According to Chan et al. (2017), an employee's intention to quit is either a cognitive decision-making process of voluntarily leaving an organization or as prevailing thoughts in an employee's mind while considering leaving an organization. The decision to leave is often not spontaneous (Greenawald 2019), but stacks up over time. This build-up period may provide the window that organizations require to dissuade an employee from leaving. This window of opportunity to intervene and motivate a decision to stay essentially spans the continuum between intention and action. Turnover intentions provide a reasonable gauge for organizations to predict turnover. Indeed, Cheng et al. (2016) argued that turnover intention is the best predictor of employee turnover, and organizations would be well-served if they continuously measured it. This study derived its impetus from this assertion and sought to examine selected variables in the call center environment that may constitute reliable predictors of employees' intention to quit (see Figure 1).

The choice of the context of call centers is informed by the reality that in contemporary society, many organizations are focusing on core competencies to consolidate their competitiveness. Consequently, organizations are reducing customer contact points and increasingly embracing call centers to communicate with customers for marketing, complaints resolution, and addressing simple requests, among other purposes. Given this rationality, there has been an increase in the number of call centers operating in South Africa. A further plausibility for this increase is that the South African call center industry attracts international organizations due to factors such as low call center staff wages, high agent productivity, low call center operating costs, and the availability of technical infrastructure (Wayde and Rogerson 2014; Antwerpen 2016). In effect, not only are call centers in South Africa servicing local companies, they are also providing services to international organizations. Hence, the Mitial Country Report (2003) suggested that call center sites in South Africa are recording significant growth and play important economic roles.

To sustain the call centers' enabled growth and stabilize their contribution to the South African economy, it is imperative to stem the tide of employee turnover. Employee turnover is a major challenge in organizations (e.g., Cooper-Thomas et al. 2012; Ibrahim 2015), and HRM scholars laud the pertinence for improving the understanding of how to optimize teamwork and performance (e.g., Opute 2014), especially in the emerging market setting (e.g., Opute and Madichie 2017; Kundu et al. 2019). Understanding HR dynamics is important (Napathorn 2018), and more contextually embedded research is essential (Batt and Banerjee 2012). There exists a plethora of anecdotal factors that may be responsible for the turnover tide and so, the need to empirically illuminate the antecedents of the staff turnover in the specific emerging market - the context of South Africa call centers-remains immense. To contribute to the understanding of turnover antecedents, we recognize a research gap and take a theoretical perspective that incorporates the core variables of customer orientation, knowledge management, and job satisfaction in understanding how employees process their decision to quit from the organizations they work for. In addition to the theoretical relevance, the findings from this study would enable practitioners to strategically organize the HRM practices to curtail the turnover tide.

This paper first explicates the theoretical premise of this study, flagging the core debates that underlie the conceptual framework and the hypotheses examined in this study. Subsequently, the methodological approach is explained. In the penultimate part of this 
paper, the findings are presented and discussed. To conclude, the theoretical as well as managerial implications are explained, and directions for future research are pinpointed.

\section{Theoretical Foundation and Statement of Hypotheses}

Behavior theory has been a major reference point for understanding what people do and the underlying stimuli (e.g., Gbadamosi 2016; Belk 2013; Opute 2017). According to that psychological viewpoint, how individuals process their decisions, such as entrepreneurial (e.g., Hagos et al. 2019), consumption (e.g., Opute 2017; Gbadamosi 2016), or employee quitor-stay decisions (e.g., Cooper-Thomas et al. 2012; Kammeyer-Mueller et al. 2005), hinges on the attributes that critically shape their mindsets. Situated in the latter theoretical domain, this study seeks to understand the intention to quit in the call center setting. Several factors can be attributed to employees' intention to quit, and these include individual, organizational, and environmental factors, among others (Chan et al. 2017; Dhar 2015; Chen et al. 2016; Nawaz and Pangil 2016). The associated losses of actual employee exit and the extended ramifications that they might have for organizational performance and customer satisfaction in the case of call centers can be profound. Hence, Yue et al. (2019) emphasized the pertinence for organizations to invest in interventions that could reverse an employee's intention to quit.

Undoubtedly, several factors explain an employee's intention to quit, and identifying the range of relevant factors for a specific context is essential toward seeking ways of effectively motivating employee retention. For instance, it is documented that career growth opportunities significantly impact turnover intentions (Nawaz and Pangil 2016). Furthermore, extant literature reveals that turnover intentions could be lowered through mentoring the staff (Lapointe and Vandenberghe 2017) and investing in corporate sponsorships (e.g., Dhar 2015). Instructively, Chen et al. (2016) declared that job satisfaction is a veritable antidote for turnover intentions. The topic of employee intention to quit is of major importance, and this study seeks to contribute to the discourse from the purview of call centers in South Africa, a geographical context and organizational unit that may differ from those reflected in the existing literature. Drawing upon strategic marketing (e.g., Opute and Madichie 2017) and HRM (e.g., Opute 2014; Chughtai and Buckley 2011) foundations, this study follows prior precedence (e.g., McNally 2007; Abdullateef et al. 2014; Aliyu and Nyadzayo 2016) and conceptualized a framework that incorporates customer orientation, knowledge management, and job satisfaction.

\subsection{Intention to Quit}

Intention to quit, defined as the employee's plan to look for alternative work as they are no longer satisfied with the current work environment (Abdullateef et al. 2014), has long been a major area of research in the management and organizational behavior field (Walsh and Bartikowski 2013; Pradhan et al. 2019). Since the intention to quit precedes an employee's resignation, the ability to identify the probable cause of the agent's intention to quit could enable an organization to convince an employee to stay. Several antecedents could contribute to the decision of an employee to voluntarily quit an organization (Pradhan et al. 2019), but a predominant factor is job dissatisfaction (Aliyu and Nyadzayo 2016).

Agent turnover in call centers is increasingly alarming. Illustrating the severity of this problem, Mwendwa and Gitonga (2017) suggested that an average of three people could fill the same call center position in a single year, and as a result, organizations incur significant financial losses. Molino et al. (2016) identified plausible turnover attributes, including exhaustion, burnout, and increased stress levels. These indicators are troubling, taking into consideration that the job of an agent often requires them to keep good countenance and maintain a friendly attitude even while responding to angry and unfriendly clients.

Another factor that contributes to an employee's intention to quit is the lack of challenging work (e.g., Stock 2016). Employees may become dissatisfied in their jobs because they undertake routine tasks that do not challenge them. This may be pronounced in 
the case of call center agents who, in addition to having repetitive and structured tasks, lack decision autonomy (Strandberg and Dalin 2010). This is likely to cause boredom or burnout and ultimately job dissatisfaction. The ultimate outcome of such a development is embracing the escape option: the intention to quit. The likely reason for that outcome is that when dissatisfaction kicks in (Aliyu and Nyadzayo 2016), the intention to quit intensifies (Abdullateef et al. 2014).

To stimulate positive employee moods, call centers should train and develop agents to manage stress (Chicu et al. 2016). Notably though, an agent's ability to deal with workrelated challenges varies from agent to agent (Stock 2016). Therefore, increasing employee autonomy and providing necessary job resources (such as knowledge management skills) can improve their ability to handle challenges and drive job satisfaction (Stock 2016). Furthermore, teamwork and the adoption of positive human resource practices can be utilized to enhance the psychological well-being of employees (Opute 2014) and negate employee's intention to quit (Chicu et al. 2016).

\subsection{Customer Orientation}

The criticality of customer orientation to identifying, meeting, and exceeding customers' expectations, as well as propelling customer loyalty and driving organizational profitability, has been reiterated in the literature (e.g., Pandey and Charoensukmongkol 2019; Narver and Slater 1990; Opute 2017; Park et al. 2018; Stock 2016; Dean 2007; Abdullateef et al. 2014; Opute 2020a; Kennedy and Laczniak 2016). Indeed, emerging market insights underline customer orientation as a critical factor of competitive advantage (e.g., Contractor 2013; Izogo 2016) while noting that customer orientation enables effective crosscultural selling (Pandey and Charoensukmongkol 2019). For corporate success, customer orientation should be the guiding vision for driving operational decisions (Kennedy and Laczniak 2016). Emphasizing this importance from the entrepreneurial orientation perspective, Opute (2020b) stressed the relevance of effectively designing and sustaining strategic marketing, which is a customer-oriented approach that fosters a better understanding of customers and their concerns so that behaviors that may endanger customer relationships can be avoided (e.g., Lussier and Hartmann 2017; Mullins et al. 2014; Lussier and Hall 2018).

Given the intangibility of services and high customer interaction and socialization, customer orientation is critical for economic success (Hennig-Thurau 2004; Opute 2020a). Reinforcing this criticality, scholars remind us that the role played by service employees shapes service quality (Opute 2020a; Dabholkar et al. 2000). Contributing to the discourse on customer orientation, Aliyu and Nyadzayo (2016) not only reminded us that the relationship with the customer needs to be managed, but also denoted that customer orientation has to do with two factors, namely enjoyment and needs. Transposed to the call center, an agent should derive enjoyment in satisfying customers' needs. Furthermore, the agent should believe in his or her ability to identify and meet customers' needs (McNally 2007). Therefore, customer orientation is an important aspect of the culture in call centers (McNally 2007), and a lack of it may make the job arduous and possibly activate an employee's intention to quit. Within the services setting, the discourse on customer orientation identifies four dimensions for measuring the construct (Donavan et al. 2004; Gazzoli et al. 2013): (1) the need to pamper the customer, (2) the need to read the customer's needs, (3) the need for a personal relationship, and (4) the need to deliver the service required.

For call center agents, two types of customer needs must be satisfied: expressed and latent. Expressed needs are explicit, while latent needs are implicit, and the challenge that the agent faces is to leverage customer orientation skills for identifying the latent needs (Blocker et al. 2011). Abdullateef et al. (2014) enhanced that view and contended that call center agents who endorse this customer orientation of an organization would effectively identify customer needs and resolve them in a satisfactory manner. Indeed, the principles of customer orientation are anchored in the role of an agent and the customer. 
Exploring customer orientation in a call center setting, McNally (2007) found that it has a positive association with job performance as well as job satisfaction. The job satisfaction contention is reinforced by further research (e.g., Babakus et al. 2011; Aliyu and Nyadzayo 2016). For example, Aliyu and Nyadzayo (2016) suggested a positive correlation between customer orientation and job satisfaction, while Babakus et al. (2011) found not only a positive association between job satisfaction and organizational commitment, but also a negative association with the intention to quit. The latter contention resonates with the position of Abdullateef et al. (2014) that there is a strong negative relationship between the organization's customer orientation and an employee's intention to quit. If the agent does not derive enjoyment from meeting customer expectations or believe in their ability to meet those needs, the agent's intention to quit may be induced, as the agent may opt for alternative options that he or she perceives to be satisfying. Grounded on these arguments, this study hypothesizes that in the call center setting in South Africa:

Hypothesis 1 (H1). There is a positive relationship between an employee's customer orientation and job satisfaction.

Hypothesis 2 (H2). There is a negative relationship between an employee's customer orientation and the intention to quit.

\subsection{Knowledge Management}

The importance of knowledge management in the organizational setting has been lauded since the 1990s (e.g., Sadeghi and Rad 2018; Politis 2001; Kianto et al. 2016). For two reasons, a continued focus on knowledge management in organizations is rational: (1) knowledge management is essential for organizations to attain and sustain competitive advantage (e.g., Abdullateef et al. 2014; Zheng et al. 2010; Kianto et al. 2016), and (2) the efficiency of knowledge management varies from one organization to the other (Sadeghi and Rad 2018; Kianto et al. 2016). Knowledge management is essential for organizational innovation and learning (Garrido-Moreno et al. 2010), and understanding how knowledge is created and utilized is vital for organizational sustainability. Knowledge includes the justified beliefs, expertise, and experiences held within an organization (Bolisani and Bratianu 2018).

According to Aliyu and Nyadzayo (2016), knowledge management encompasses an organization's ability to create, store, manage, use, and share knowledge for organizational efficiency and effectiveness. Similarly, Donate and de Pablo (2015, p. 362) referred to Alavi and Leidner (2001) as well as Zack et al.'s (2009) definition of knowledge management as "a set of activities, initiatives, and strategies that companies use to generate, store, transfer, and apply knowledge for the improvement of organizational performance". In a more recent contribution, Sadeghi and Rad (2018) conceptualized knowledge management as involving an organization's ability to leverage acquired knowledge to achieve competitiveness. Organizations must learn and adapt to survive and grow in a continuously changing competitive landscape (Bhaskar and Mishra 2017). Consequently, to effectively adapt to changes in the business environment and stay competitive, call centers need to generate and harness knowledge. Endorsing such a knowledge management approach, organizations can effectively acquire, integrate, share, and apply knowledge in building competitive advantage (Garrido-Moreno et al. 2010).

Donate and de Pablo (2015) delineated four core aspects of knowledge management: (1) knowledge creation, which involves replacing old knowledge with new knowledge or finding new competitive ways of doing business; (2) knowledge storage, which implies preserving knowledge for future use whenever needed; (3) knowledge transfer, which entails the intra- or interorganizational sharing of knowledge; and (4) knowledge application, which relates to utilizing knowledge in the most efficient and beneficial way to aid organizational functioning. For their part, Kianto et al. (2016) conceptualized five knowledge management facets: knowledge acquisition, knowledge sharing, knowledge creation, knowledge codification, and knowledge retention. 
The discourse on knowledge management alludes to how knowledge management would facilitate organizational effectiveness. To compete effectively, organizations must ensure customer satisfaction. We argue that effectively satisfying the customers in the call center setting hinges on their ability to manage knowledge. Unsurprisingly, Khodakarami and Chan (2014) contend that call center agents should have profound knowledge of the information to be shared with customers during calls. When agents have the know-how and access to knowledge relevant to solving customers' problems, it is likely to improve their job satisfaction. That notion is supported by Kianto et al. (2016), who investigated Finnish municipal organizations and found a significant positive correlation between knowledge management and job satisfaction. Elaborating their findings, they note that knowledge sharing plays a fundamental role in promoting employee job satisfaction, however differentiated by job characteristics. Furthermore, they noted that knowledge sharing does not only facilitate employee job satisfaction, but it also improves employee well-being. Insight from Malaysian call centers (Aliyu and Nyadzayo 2016) reinforces and extends Kianto et al. (2016): effective knowledge management would lead to an increase in agent job satisfaction and reduction in intention to quit. A plausible rationale for these outcomes is that knowledge management facilitates an organization's ability to create better work methods that could bolster employee morale and therefore drive job satisfaction. It is against this background that this study hypothesizes that:

Hypothesis $3 \mathbf{~ ( H 3 ) . ~ T h e r e ~ i s ~ a ~ p o s i t i v e ~ r e l a t i o n s h i p ~ b e t w e e n ~ k n o w l e d g e ~ m a n a g e m e n t ~ a n d ~ j o b ~}$ satisfaction.

Hypothesis $4 \mathbf{( H 4 ) . ~ T h e r e ~ i s ~ a ~ n e g a t i v e ~ r e l a t i o n s h i p ~ b e t w e e n ~ k n o w l e d g e ~ m a n a g e m e n t ~ a n d ~ t h e ~}$ intention to quit.

\subsection{Job Satisfaction}

Job satisfaction is considered a relative concept. Basically, one can be satisfied with one's job because of certain factors, whereas in a different organization, those factors may not be influential. Customer centrism is essential for organizational marketability, but that cannot be achieved without ensuring employee job satisfaction (Molino et al. 2016). McNally (2007) as well as Babakus et al. (2011) posit that there should be a balance between customer centrism and ensuring employee well-being. If agents find their work to be non-intrinsically and extrinsically rewarding, it can affect their efficiency and effectiveness in completing tasks. Job satisfaction is linked to the employees' emotions, feelings, and attitudes toward the work, other employees, remuneration, and culture of an organization (Abdullateef et al. 2014; Sims et al. 2016). These insights extend the literature, which lauds the importance of job satisfaction to organizational commitment and employee retention (Donavan et al. 2004). Enhancing these theoretical contentions, job dissatisfaction has been documented to exert a detrimental effect on customer service quality and advertently affect organizational success (Mwendwa and Gitonga 2017; Iwu and Ukpere 2013).

According to Abdullateef et al. (2014), job satisfaction is when an agent (employee) holds favorable emotions and attitudes toward the job. Supporting that foundation, Sims et al. (2016) not only portrayed job satisfaction as concomitant with employee satisfaction, but also attributed that outcome to the existence of a conducive organizational climate. Extending the organizational climate and outcome substance, Strandberg and Dalin (2010) not only lamented the inflexibility of call center employees and the monotonous, structured, and highly stress-laden nature of their tasks, but also underlined the impact of low staff morale as well as the intention to quit. The monotonous substance of call center agents' tasks was echoed by Mwendwa and Gitonga (2017). Sometimes, standards are set for agents and, if they fall short and fail to manage their work stress, it might lead to employee burnout, absenteeism, or an increase in their intention to quit the job (Chicu et al. 2016; Pradhan et al. (2019). It is possible that employees that experience work stressors would be dissatisfied, and dissatisfied employees would be more predisposed towards quitting their jobs and search for new jobs. This argument synchronizes with the finding of Feyerabend 
et al. (2018) that job satisfaction has a negative correlation with the intention to quit. This finding was corroborated by Walsh and Bartikowski (2013), who also noted a negative correlation between job satisfaction and the intention to quit. Drawing from the above discourse, this study contends that in the specific context of call centers in South Africa:

Hypothesis 5 (H5). There is a negative relationship between job satisfaction and intention to quit.

Hypothesis 6 (H6). Job satisfaction positively mediates the relationship between customer orientation and intention to quit.

In addition, based on the analogy in Section 2.3, the following is also hypothesized:

Hypothesis 7 (H7). Job satisfaction positively mediates the relationship between knowledge management and intention to quit.

Figure 1 captures the conceptual framework for this study and includes seven hypotheses grounded in the core debates in the literature on customer orientation, knowledge management, job satisfaction, and intention to quit.

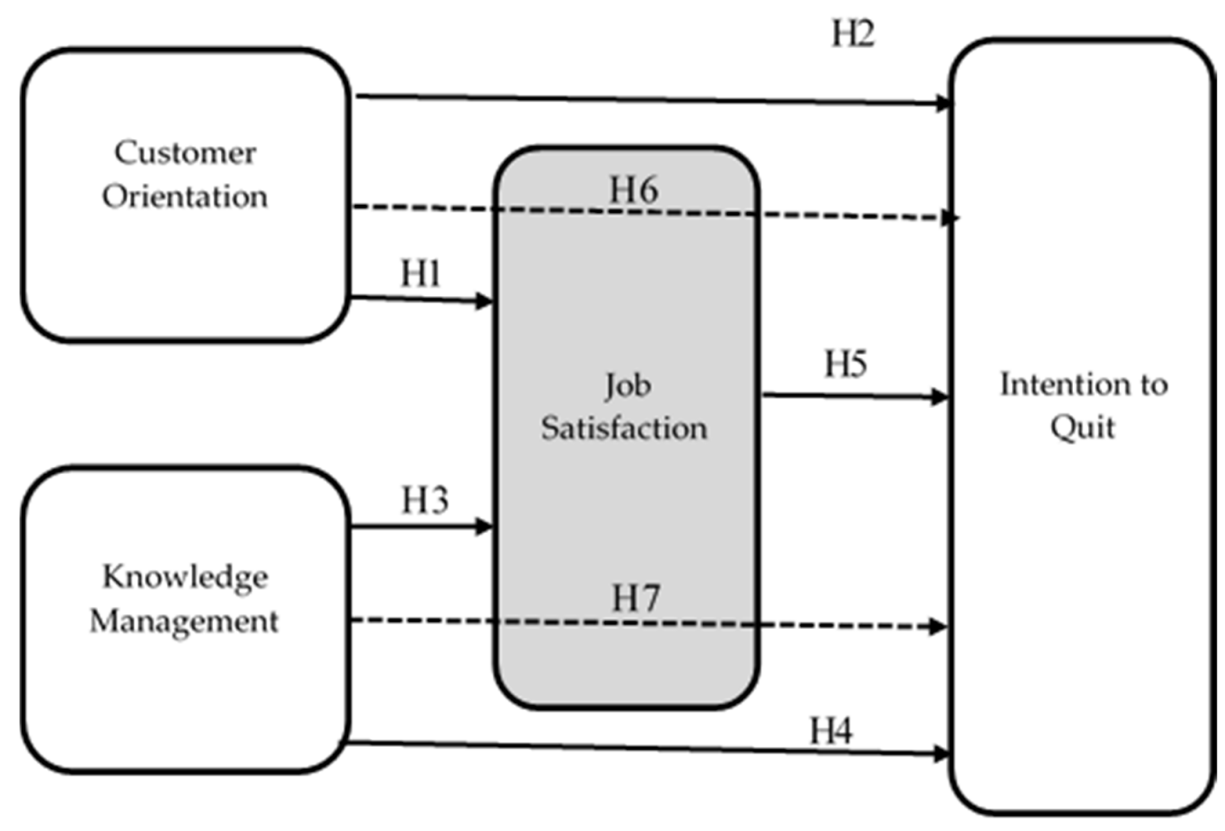

Figure 1. Conceptual framework.

The conceptual model for this study is grounded in social exchange theory (SET), which portrays factors such as employee job satisfaction as a mediator in the relationships that are key to attrition rates in organizations (Witt and Wilson 1990). The relevance of social exchange theory in exploring the call center industry, especially from the point of relationships between key performance indications and their impacts on employee performance and commitment to the organization, has been documented in the literature (Molm et al. 2000; Abdullateef et al. 2014). Further literature on call centers and service marketing reinforce this relevance in evaluating the relationships between employees, the immediate supervisors, and the organizational policies (Aliyu and Nyadzayo 2016). Thus, the organization's ability to effectively define each employee's responsibilities is a component of SET in perceived organizational support for the employees (Lynch et al. 1999). Leveraging on the SET, Ertürk and Vurgun (2015) agree that perceived organizational support will inversely influence employees' intentions to quit. 


\section{Research Methodology}

\subsection{Sample and Survey Instrument}

South Africa, which has been categorized as an emerging market (Morgan Stanley Capital International (MSCI); Central Intelligence Agency 2019), was the geographical setting of this study. Typical characteristics of emerging markets include a low per capita income, high volatility (driven by three factors: natural disasters, external price shocks, and domestic policy instability), volatile currency swings, and high risk-induced potential for growth (Morgan Stanley Capital International (MSCI)). Thriving in such a challenging economic setting requires a strategic operational approach that drives performance enhancement. This is in line with the operational foundation that this study leans on to examine employees' intentions to quit in the South African call center setting.

Quantitatively based, a questionnaire was used in this study to collect data from call center agents. Given that the population of call center agents is sizable, the directory of the professional body of call center agents in South Africa was utilized in determining the sample for this study. Convenience sampling (e.g., Saunders et al. 2012) was used in identifying the participants in this study. The hallmark of any reputable study is the adherence to ethical guidelines (Leedy and Ormrod 2014), and as such, before data was collected, ethics approval was sought from the researcher's university. To obtain ethical clearance, we needed to be granted permission from the participating firm. In requesting permission, it was necessary to state that all data would be used anonymously, thereby assuring respondents privacy and confidentiality. We also indicated that participants were free to withdraw from the study at any time, but more importantly, they were at liberty to not answer any question they felt uncomfortable with. Hair et al. (2019) counseled that adherence to ethical standards in research equally requires a clear explanation of the nature, aim, and importance of the study. From the directory of the professional body of call center agents, a call center was selected, and the questionnaire was emailed to the manager for distribution to employees. To explore the South African context, the research instrument was adapted from past validated call center studies. The two latent and the mediating and dependent variables were measured using a five-point Likert scale $(1=$ strongly disagree; 5 = strongly agree).

To identify potential problems in the questionnaire design, we followed the methodological benchmark of 5-10 (Bush 2012) and pilot-tested the survey instrument with 10 respondents (e.g., Opute and Madichie 2017). Justified by the pilot-testing evidence, the survey instrument was revised and contained nineteen (19) measures (see Table 1). The customer orientation construct was measured using five-items from past studies (Choi et al. 2014; Aliyu and Nyadzayo 2016), while the five measures for knowledge management had also been previously used in studies (e.g., Sin et al. 2005; Aliyu and Nyadzayo 2016). Similarly, to measure job satisfaction, this study adapted five measures validated in past studies (LeRouge et al. 2006; Aliyu and Nyadzayo 2016). Finally, following methodological precedence (Gianfranco 2011; Aliyu and Nyadzayo 2016), four items were used to measure the intention to quit construct.

\subsection{Data Analysis}

To ensure suitability of the data for relevant analysis for examining the conceptualized framework, two major steps were taken (Field 2009). First, preliminary data screening was undertaken. Second, analytical steps were taken to confirm the reliability and validity of the data. After this, inferential statistical tests were carried out.

Data screening and preliminary analyses were conducted, in which 224 questionnaires were returned. Following a preliminary analysis guide (see Byrne 2010; Kantsperger and Kunz 2005; Field 2009), five questionnaires were eliminated from the analysis due to missing values. Thus, the analytical sample for this study was 219 . The sample for this study consisted of 152 females $(67.86 \%)$ and 67 males (32.14\%). The majority of the respondents (192, or 87.7\%) were aged between 18 and 34 years. Adhering to Byrne (2010), the study utilized the Levene's test for equality of variance to check for response bias. The 
results from the comparison between the early and late respondents confirmed no response bias in this research.

Quantitatively examining the conceptual framework involved calculating the descriptive and regression estimates through structural equation modeling (SEM) analysis. Using SEM, we examined the influence of the independent and mediating variables on the dependent variables, with the aim of determining the extent to which the data was consistent with the hypothesized relationships in the model (e.g., Byrne 2010; Hu and Bentler 1999). To ensure suitability for examining the conceptualized relationships through SEM analysis, reliability and validity screening of the data was undertaken (Byrne 2010). Table 1 shows the reliability and validity estimates for customer orientation, knowledge management, employee job satisfaction, and intention to quit.

Table 1. Results of validity and reliability analysis.

\begin{tabular}{|c|c|c|c|}
\hline Constructs & & FL & $\alpha$ \\
\hline Customer orientation (CO) & & & 0.82 \\
\hline $\mathrm{CO} 1$ & The customer is at the center of strategic planning in our organization & 0.67 & \\
\hline $\mathrm{CO} 2$ & $\begin{array}{c}\text { Meeting the customer's needs and expectations is the commitment of } \\
\text { our organization }\end{array}$ & 0.73 & \\
\hline $\mathrm{CO} 3$ & In our organization, customer databases are regularly updated & 0.58 & \\
\hline $\mathrm{CO} 4$ & $\begin{array}{l}\text { The use of customer knowledge and information in the decision-making } \\
\text { process in our organization gets strong support and commitment from } \\
\text { our management }\end{array}$ & 0.73 & \\
\hline CO5 & $\begin{array}{l}\text { All service standards are based on consistent analysis of the customers' } \\
\text { needs in our organization }\end{array}$ & 0.79 & \\
\hline Knowledge Management (KM) & & & 0.79 \\
\hline KM1 & $\begin{array}{l}\text { Customers can expect prompt service from employees of } \\
\text { my organization }\end{array}$ & 0.52 & \\
\hline KM2 & $\begin{array}{l}\text { Customer information is shared across all points of contact in } \\
\text { our organization }\end{array}$ & 0.63 & \\
\hline KM3 & $\begin{array}{l}\text { Our employee training programs are designed to develop the skills } \\
\text { required for acquiring and deepening customer relationships }\end{array}$ & 0.55 & \\
\hline KM4 & $\begin{array}{l}\text { My organization believes that mining data intelligently is a source of } \\
\text { competitive advantage }\end{array}$ & 0.69 & \\
\hline KM5 & $\begin{array}{c}\text { Knowledge is shared to leverage the value of customer information in } \\
\text { our organization }\end{array}$ & 0.67 & \\
\hline Employee Job Satisfaction (EJS) & & & 0.72 \\
\hline EJS1 & I would describe my work as satisfying & 0.89 & \\
\hline EJS2 & I would describe my work as giving a sense of accomplishment & 0.86 & \\
\hline EJS3 & I would describe my work as fascinating & 0.74 & \\
\hline EJS4 & I would describe my work as useful to the organization & 0.43 & \\
\hline EJS5 & $\begin{array}{c}\text { The responsibilities of each employee are clearly defined, assigned, and } \\
\text { understood in our organization }\end{array}$ & 0.77 & \\
\hline Intention to Quit (ITQ) & & & 0.68 \\
\hline ITQ1 & I often think of leaving my present job & 0.71 & \\
\hline ITQ2 & I intend to leave this organization within the next 12 months & 0.62 & \\
\hline ITQ3 & $\begin{array}{l}\text { I would not reject a job offer by another company if it comes at } \\
\text { any moment }\end{array}$ & 0.44 & \\
\hline ITQ4 & I know of another colleague who has decided to leave this organization & 0.55 & \\
\hline
\end{tabular}


The Cronbach's alpha estimates ranged from 0.68 to 0.82 , statistical evidence that suggests internal consistency of the conceptualized factors (see Hair et al. 2010). At 0.68, the Cronbach's alpha for intention to quit measured favorably with the standard for confirming internal consistency in past studies (see, for example, Crossley et al. 2007; Chen and Tsai 2007; Leung and Lee 2006; Aliyu and Nyadzayo 2016), with all studies exploring one form of individual intention or the other. Reinforcing the validity for this internal consistency conclusion, despite a Cronbach's alpha value below 0.7, Miller (1995) contended that a lower internal consistency is expected for a more homogeneous sample. Methodologists warn that Cronbach's alpha may be inadequate for confirming internal consistency in a construct and therefore recommend the use of composite reliability to support Cronbach's alpha estimates (e.g., Jöreskog 1971). Adhering to that logic, we estimated the composite reliability (CR) for each factor, giving due consideration to the cut-off value of 0.60 (Nunnally and Bernstein 1994). The composite reliability results for this study were satisfactory for customer orientation (0.86), knowledge management (0.83), job satisfaction (0.87), and intention to quit (0.79).

Consistent with the structural equation modeling literature (e.g., Kantsperger and Kunz 2005; Yim et al. 2005), a two-step data analysis approach was used in this research. First, exploratory factor analysis (EFA) was undertaken to evaluate the measurement instruments. Subsequently, further validation of the instruments through a structural model (confirmatory factor analysis (CFA)) was undertaken. In the first stage, items that showed insufficient levels of the standard indicator reliability were deleted. Table 1 summarizes the measurement items that were considered in the structural model analyses. The factor loadings for each construct were reasonably high and compared well with prior research (e.g., Park et al. 2018; Aliyu and Nyadzayo 2016; Crossley et al. 2007). From the evidence in Table 1 above, the items for each factor were appropriate measures for the constructs at the 0.5 loading benchmark (e.g., Conway and Huffcutt 2003; Byrne 2010; Park et al. 2018; Chen and Tsai 2007). In this study, two items were loaded the 0.4 level but retained as appropriate measures of their constructs (e.g., Field 2009; Crossley et al. 2007).

As stated earlier, the questionnaires for this study were e-mailed to the manager of a call center agent to distribute to respondents. In other words, this study had only one informant organization: a dispensation that created common method bias (Podsakoff et al. 2003). Consequently, to justify discriminant validity, it was important to carry out a common method variance (CMV) test (Podsakoff et al. 2003; Fornell and Larcker 1981). To check for CMV, we performed Harman's single factor test. All principal constructs were put into the factor analysis. According to Podsakoff et al. (2003), when the factor analysis captured only one factor or a single general factor accounting for most of the covariance, then CMV existed. In this study, neither one factor nor a single general factor accounted for a majority of the variance. There was no common method bias in this study; the first factor accounted for 30.21 percent, while the total variance explained was 73.45 percent.

The study's CFA model made up of four latent variables, and 24 measurement items were analyzed using AMOS v.24. The structural model results for this study demonstrated acceptable goodness of fit estimates $\left(\chi^{2}=59.73, \chi^{2} / \mathrm{df}=1.012, p<0.449, \mathrm{CFI}=0.99\right.$, GFI $=$ $0.96, \mathrm{RFI}=0.912, \mathrm{NFI}=0.93, \mathrm{RMSEA}=0.08)$. Based on the recommended structural model thresholds (Hair et al. 2010), the statistical results achieved in this study were significant (See Table 2). Based on the results, the constructs for this study demonstrated acceptable validity levels and measured the conceptualized constructs.

To consolidate the goodness of fit evidence for this study and further ensure suitability for regression investigation of the conceptualized hypotheses, discriminant analysis was performed to confirm the distinctness of the constructs. To establish discriminant validity, we followed the methodological guideline (Fornell and Larcker 1981) by estimating the average variance extracted (AVE). Tables 3 and 4 confirm the acceptable level of discrimination, with the achieved estimates measuring favorably with the benchmark (Fornell and Larcker 1981). 
Table 2. Model fits for the study constructs.

\begin{tabular}{ccc}
\hline Final Models & Thresholds & Results \\
\hline CMIN/df & $<5$ & 1.012 \\
$p$-value & $\geq 0.05$ & 0.449 \\
GFI & $\geq 0.9$ & 0.961 \\
CFI & $\geq 0.95$ & 0.999 \\
RFI & $\geq 0.9$ & 0.912 \\
NFI & $\geq 0.9$ & 0.933 \\
RMSEA & $\leq 0.08$ & 0.008 \\
\hline
\end{tabular}

Table 3. Variance extracted.

\begin{tabular}{|c|c|c|c|c|c|}
\hline Variable & Code & $\begin{array}{l}\text { Square Multiple } \\
\text { Correlation (SMC) }\end{array}$ & $S_{M C}{ }^{2}$ & $\begin{array}{l}\text { Standardized } \\
\text { Error (SE) }\end{array}$ & $\begin{array}{c}\text { Variance } \\
\text { Extracted (VE) }\end{array}$ \\
\hline \multirow[t]{6}{*}{$\begin{array}{l}\text { Customer } \\
\text { Orientation }\end{array}$} & $\mathrm{CO} 1$ & 0.318 & 0.101124 & 0.081 & \\
\hline & $\mathrm{CO} 2$ & 0.373 & 0.139129 & 0.081 & \\
\hline & $\mathrm{CO} 3$ & 0.530 & 0.2809 & 0.082 & \\
\hline & $\mathrm{CO} 4$ & 0.646 & 0.417316 & 0.082 & \\
\hline & $\mathrm{CO} 5$ & 0.506 & 0.256036 & 0.086 & \\
\hline & & & 1.194505 & 0.412 & 0.744 \\
\hline \multirow[t]{6}{*}{$\begin{array}{l}\text { Knowledge } \\
\text { Management }\end{array}$} & KM1 & 0.085 & 0.007225 & 0.076 & \\
\hline & KM2 & 0.473 & 0.223729 & 0.078 & \\
\hline & KM3 & 0.593 & 0.351649 & 0.068 & \\
\hline & KM4 & 0.435 & 0.189225 & 0.081 & \\
\hline & KM5 & 0.278 & 0.077284 & 0.080 & \\
\hline & & & 0.849112 & 0.383 & 0.689 \\
\hline \multirow[t]{6}{*}{ Job Satisfaction } & JS1 & 0.801 & 0.641601 & 0.083 & \\
\hline & JS2 & 0.633 & 0.400689 & 0.085 & \\
\hline & JS3 & 0.023 & 0.000529 & 0.081 & \\
\hline & JS4 & 0.068 & 0.004624 & 0.098 & \\
\hline & JS5 & 0.251 & 0.063001 & 0.096 & \\
\hline & & & 1.110444 & 0.443 & 0.715 \\
\hline \multirow[t]{5}{*}{ Intention to Quit } & IQ1 & 0.197 & 0.038809 & 0.084 & \\
\hline & IQ2 & 0.156 & 0.024336 & 0.095 & \\
\hline & IQ3 & 0.411 & 0.168921 & 0.095 & \\
\hline & IQ4 & 0.232 & 0.053824 & 0.090 & \\
\hline & & & 0.28589 & 0.364 & 0.440 \\
\hline
\end{tabular}

Table 4. Discriminant validity through average variance extracted (AVE).

\begin{tabular}{ccccc}
\hline Variable Name & $\mathbf{1}$ & $\mathbf{2}$ & $\mathbf{3}$ & $\mathbf{4}$ \\
\hline Customer Orientation (1) & 1.000 & & & \\
Knowledge Management (2) & 0.717 & 1.000 & & \\
Job Satisfaction (3) & 0.730 & 0.702 & 1.000 & 1.000 \\
Intention to Quit (4) & 0.592 & 0.565 & 0.578 & \\
\hline
\end{tabular}


Ranging from 0.565 to 0.730 (see Table 4), the ratio for all the four latent variables were above the suggested threshold $(\geq 0.50)$ (Fornell and Larcker 1981). These statistical results lend support to the overall validity of the constructs used in measuring both the exogenous variables (customer orientation and knowledge management) and endogenous variables (job satisfaction and intention to quit).

As shown in Figure 1, while H1, H2, H3, H4 and H5 capture direct relationships, H6 and H7 capture mediating relationships. Structural model estimation was undertaken to test the relationships between the independent variables (customer orientation and knowledge management), mediating variable (job satisfaction) and dependent variable (intention to quit). Figure 2 and Table 5 summarize the structural model results for the direct relationships ( $\mathrm{H} 1, \mathrm{H} 2, \mathrm{H} 3, \mathrm{H} 4$, and $\mathrm{H} 5)$.

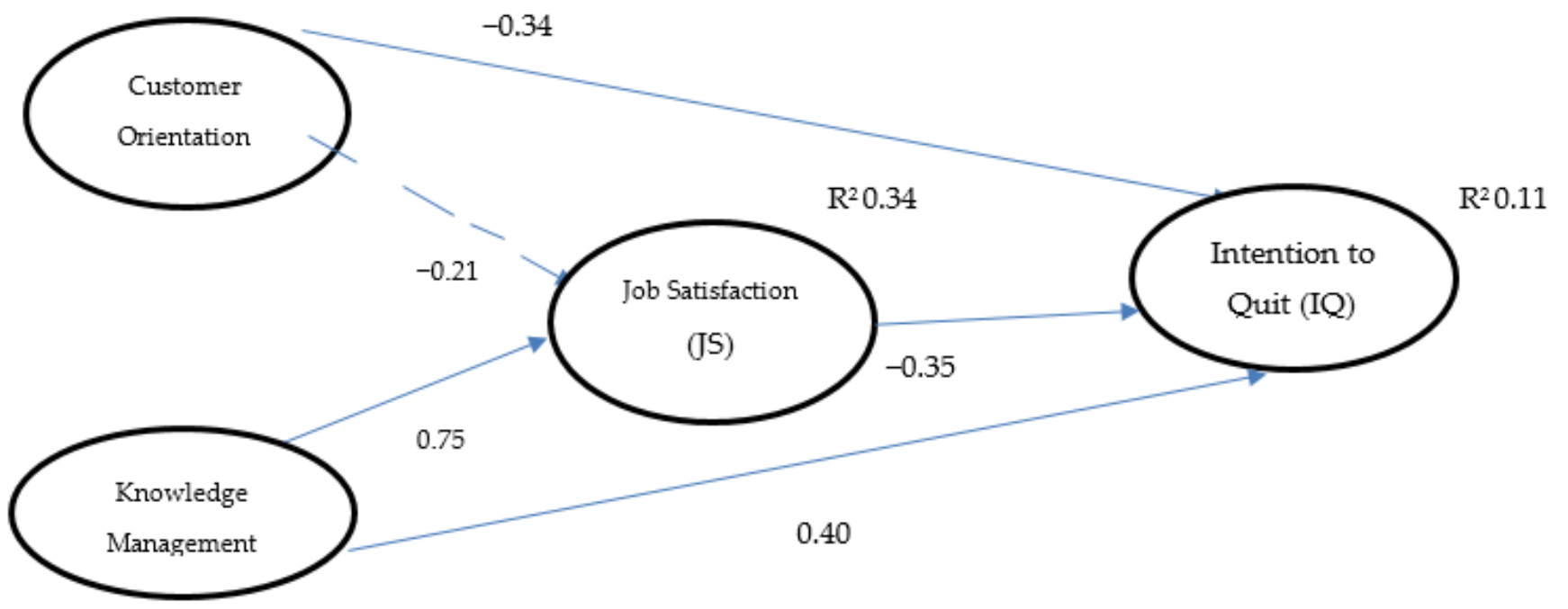

Figure 2. Path diagram from AMOS analysis.

Table 5. Regression results.

\begin{tabular}{ccccccccc}
\hline Hypotheses & Relationships & Estimate & SE & CR & $p$-Value & Label & $\mathbf{R}^{2}$ & Conclusion \\
\hline H1 & JS $\leftarrow$ CO & -0.349 & 0.380 & 0.919 & 0.358 & Not Sig & Not Supported \\
\hline H3 & JS $\leftarrow$ KM & 1.331 & 0.453 & 2.936 & 0.003 & Sig ** & Supported \\
\hline H2 & IQ $\leftarrow$ CO & -0.763 & 0.423 & -1.802 & 0.072 & Sig $^{*}$ & Supported \\
\hline H4 & IQ $\leftarrow$ KM & 0.970 & 0.541 & 1.794 & 0.073 & Sig * $^{*}$ Not Supported \\
\hline H5 & IQ $\leftarrow$ JS & -0.480 & 0.139 & -3.453 & 0.000 & Sig ** & Supported \\
\hline JS & & & & & & 0.344 \\
\hline
\end{tabular}

${ }^{*} p<0.10 .{ }^{* *} p<0.05 .{ }^{* * *} p<0.01$. Notes: $\mathrm{H}=$ hypothesis; $\mathrm{Sig}=$ significant; Not $\mathrm{Sig}=$ not significant; JS = job satisfaction; $\mathrm{CO}=$ customer satisfaction; $\mathrm{KM}=$ knowledge management; and $\mathrm{IQ}=$ intention to quit.

According to Byrne (2010), structural equation modeling is the most powerful approach to quantitatively test the mediating effects of the combined relationships between multiple independent and dependent variables in a single fit regression model. In line with the conceptualized framework (Figure 1), the mediating influence of job satisfaction was gauged, and the results are summarized in Table 6. 
Table 6. Results mediating the hypotheses.

\begin{tabular}{cccccccc}
\hline Hypotheses & Exogenous & Mediator & Endogenous & $\begin{array}{c}\text { Direct Effect } \\
\text { Estimates }\end{array}$ & $\begin{array}{c}\text { Indirect Effects } \\
\text { Estimates }\end{array}$ & $\begin{array}{c}\text { Mediating } \\
\text { Hypotheses }\end{array}$ \\
\hline $\mathrm{H} 6$ & $\mathrm{CO}$ & $\longrightarrow \mathrm{JS}$ & $\mathrm{IQ}$ & -0.339 & 0.074 & Mediating \\
\hline $\mathrm{H} 7$ & $\mathrm{KM}$ & $\longrightarrow \mathrm{JS}$ & $\mathrm{IQ}$ & 0.397 & -0.261 & Not Mediating \\
\hline
\end{tabular}

\section{Findings}

For the conceptualized direct relationships, statistical support was found for $\mathrm{H} 2, \mathrm{H} 3$, and H4. At $\beta=-0.763(p=0.072), \mathrm{H} 2$ was supported; there was a negative relationship between customer orientation (CO) and the intention to quit (IQ) at a significance level of 0.10 . Thus, higher customer orientation would lead to a lower intention to quit. The conclusion of support for $\mathrm{H} 2$ was rationalized on the logic that due to the magnitude effect of the sample size, a conclusion based on a 10\% significance level was valid (Richard 1986). Reinforcing that validity, Wasserstein and Lazar (2016) underlined that despite smaller $p$-values, statistical results could still be scientifically meaningful when an advanced analytical tool like AMOS is used to establish satisfactory fit indices, and this was the case in this study. For the second conceptualized relationship involving customer orientation, statistical significance was not found. At $\beta=-0.349(p=0.358)$, customer orientation had a negative and statistically insignificant relationship with employee job satisfaction. Thus, H1 was not supported, a finding that contrasted with the prior literature, which suggested a positive association of customer orientation with employee job satisfaction (e.g., Babakus et al. 2011; Aliyu and Nyadzayo 2016).

Regarding knowledge management, support was found (H3) but also negated (H4) from the point of direct relationship. At $\beta=1.331(p=0.003)$, this study demonstrated a positive and statistically significant association of knowledge management with employee job satisfaction. Thus, H3 was supported, a finding that resonated with the trend in Malaysian call centers (Aliyu and Nyadzayo 2016) and Finnish organizations (Kianto et al. 2016). Statistically ( $\beta=0.970$ and $p=0.073$ ), H4 was rejected; no significant negative association was found between knowledge management and the intention to quit. To the contrary, considering a significance level of 0.10 , this study seemed to suggest that there may be a positive association between knowledge management and the intention to quit. An examination of the direct relationship between job satisfaction and intention to quit, as hypothesized in $\mathrm{H} 5$, captured values of $\beta=-0.480$ and $p=0.000$. This statistical evidence indicates that job satisfaction had a significant negative relationship with the intention to quit. Based on that statistical result, $\mathrm{H} 5$ was supported.

Besides the direct relationships between study constructs, it was hypothesized that job satisfaction would mediate the relationships that the independent variables of customer satisfaction and knowledge management had with the dependent variable of the intention to quit. For the mediating variables, the R-square value of 0.344 indicates that $34 \%$ of the variance in job satisfaction was collectively explained by customer orientation and knowledge management. The remaining $66 \%$ would be determined by other variables that were not conceptualized in this model. The R-square value of 0.107 indicates the combined strength of the relationships between the customer orientation, knowledge management, job satisfaction and intention to quit. This goodness of fit measure indicates that $11 \%$ of the variance in the intention to quit was explained by customer orientation, knowledge management, and job satisfaction. The remaining $89 \%$ could be explained by other variables that were not conceptualized in this model.

The statistical results showed that in the studied population of call center agents, job satisfaction fully mediated the effect of customer orientation on employees' intentions to quit. The plausibility of full mediation was premised on the evidence that the direct effect estimate of -0.339 was lower than the indirect effect estimates of 0.074 . Based on that evidence, $\mathrm{H} 6$ was statistically supported. From the point of possible mediation of job 
satisfaction in the relationship between knowledge management and the intention to quit, the statistical results reflected 0.397 and -0.261 for the direct effect estimate and the indirect effect estimate, respectively. Given that the indirect effect estimate in this case was less than the direct effect estimate, this implies that the conceptualized hypothesis of a mediating influence of job satisfaction on the relationship between knowledge management and the intention to quit was not valid, and thus, H6 was not supported.

\section{Discussion}

Situated in the internal marketing viewpoint (e.g., Choi and Joung 2017; Kotler and Armstrong 2012), this study examined the extent to which employee job satisfaction and intention to quit were imparted by customer orientation and knowledge management in the call center setting. This study contributes to the understanding of the internal marketing approach from the point of employee retention, an outcome that is critical for organizations to profitably satisfy customers (Choi and Joung 2017; Kotler and Armstrong 2012). This study aimed specifically to illuminate the aforementioned relationships to improve the understanding of call center attrition in an emerging economy (South Africa). Empirically, this study suggests that ensuring employee job satisfaction is an effective tool for mitigating the employee intention to quit (e.g., Pradhan et al. 2019; Walsh and Bartikowski 2013). In other words, when employees are satisfied with their jobs, they will be motivated to stay in their jobs and the firms they work for. Further empirical insights from this study illuminate the associated organizational components from the point of direct association to job satisfaction and the intention to quit, as well as the mediating capacity of job satisfaction in the association between organizational components and the intention to quit. Thus, the findings from this study contribute to the understanding of the network of relationships that explain employee intention to quit behavior (e.g., Aliyu and Nyadzayo 2016; Park et al. 2018; Abdullateef et al. 2014; Aladwan et al. 2013; Pradhan et al. 2019).

For ensuring employee job satisfaction to motivate employees to remain with their organizations, employees' responsibilities must be clearly defined and understood, in addition to tasks being structured in a manner that is fascinating and satisfying. These insights reinforce the organizational socialization literature which not only underlined the importance of job satisfaction toward achieving employee retention (e.g., Walsh and Bartikowski 2013; Aliyu and Nyadzayo 2016), but also the significance of role clarity in driving employee job satisfaction (e.g., Cooper-Thomas et al. 2012; Aliyu and Nyadzayo 2016; Kammeyer-Mueller et al. 2005).

A core take from this study is the centrality of employee job satisfaction to employee retention at $\beta=-0.480(p=0.000)$. Equally underlined in this study is the network of relationships that aid the understanding of employees quit or stay decisions. While customer orientation does not influence job satisfaction, which contrasts several works (e.g., Park et al. 2018; Aliyu and Nyadzayo 2016; Babakus et al. 2011) but supports Auh et al. (2016), higher customer orientation would contribute to a lower intention to quit (e.g., Park et al. 2018; Aliyu and Nyadzayo 2016). Interestingly, a significant positive mediating influence of job satisfaction on the relationship between customer orientation and the intention to quit was found in this study. These results imply that while the customer orientation practices of the call center explored in this study may lead to a lower intention to quit, the practices are ineffective at driving employee job satisfaction. As a result, enforcing the customer orientation practices as a way of driving employee job satisfaction may lead to a high intention to quit. This insight may be suggesting that if there is an intensified push to enable employee satisfaction through customer orientation, this would increase employee stress (e.g., Auh et al. 2016) and by extension aggravate the intention to quit.

Within the population for this study, knowledge management would enhance employee job satisfaction, statistical evidence that contrasts Aliyu and Nyadzayo (2016) but supports Sin et al. (2005). In other words, if call centers enforce knowledge management practices, such as employees responding swiftly to customers' service needs, accurate sharing of customers' information across all contact points, appropriate data mining, and 
effective knowledge sharing to leverage customer information value, they would enhance employee job satisfaction. The rationale in that outcome is that since the organization gives due attention to mining data, shares knowledge and information accurately, and thereby enables employees to effectively respond to customers' needs, this will motivate employees to be satisfied with their jobs. Interestingly however, contrary to expectation, this study suggests that knowledge management may correlate positively with the intention to quit. Though at a very low significance level $(p=0.10)$, this study indicates that the more knowledge management is enforced, the higher the intention to quit propensity. Even more interesting is the evidence that job satisfaction does not mediate the relationship between knowledge management and intention to quit. According to Wong (2005), the efficacy of knowledge management practices hinges on the operational issues and various other factors such as leadership, structure, culture, roles and responsibilities, IT equipment and measurement. Bearing that foundation in mind, we conclude that the association between knowledge management and the intention to quit and the mediating impact of job satisfaction in the explored call center may be explained by factors not captured in this study.

\section{Managerial Implications}

For organizations aiming for market orientation and corporate success, internal marketing is a core strategy (Choi and Joung 2017). Recognizing that satisfying internal customers (i.e., employees) would enable organizations to provide external customers a higher quality of service (e.g., Choi and Joung 2017; Kotler and Armstrong 2012), employee intention to quit was examined in this study. Understanding employee intention to quit dynamics is of central importance to organizations (e.g., Aliyu and Nyadzayo 2016; Park et al. 2018; Aladwan et al. 2013) because of the increasing challenge of retaining their employees (e.g., Ibrahim and Al Falasi 2014; Suliman and Obaidli 2011) despite the high cost of recruiting new employees (e.g., Ashforth et al. 2007; Ibrahim and Al Falasi 2014). This study offers insights that would enable call centers in the explored context to effectively address the employee retention challenge. Given the fundamental role that call centers play in the service landscape in South Africa, practitioners within settings that are homogeneous in features can leverage the insights from this study to strategically structure their efforts toward galvanizing job satisfaction and driving employee retention. If they effectively manage the internal marketing dynamics, organizations will not only recoup their recruitment and training investments in the employees, but also, over time, compete more effectively in the market (Choi and Joung 2017; Kotler and Armstrong 2012).

To maximize the employee retention benefits of job satisfaction, managers in the explored population must ensure suitable measures of other internal organizational factors that may aid these outcomes, either directly or through a mediating influence. In that regard, managers in the explored call center setting must bear in mind that, although a customer orientation focus would contribute to a lower intention to quit, it may not aid job satisfaction. On the contrary, a blind enforcement of customer orientation may impact employee job satisfaction negatively. Although no significant positive relationship was found between customer orientation and employee job satisfaction, call center practitioners are reminded that job satisfaction significantly mediates the relationship between customer orientation and the intention to quit.

The attention of call center practitioners is also drawn to the notion of a likely relationship between knowledge management, employee job satisfaction and employee intention-to-quit. Contrary to hypothesis, this study found no mediating influence of job satisfaction on the relationship between knowledge management and employee intentionto-quit. Analysing that evidence in tandem with the insight that employee intention-to-quit propensity may be aggravated by knowledge management, though at a low significance level $(p=0.10)$, managers in the explored call-centre domain are reminded of the need for a precautionary approach in the adoption of knowledge management. 
To effectively respond to the employee retention challenge, call center managers should continuously promote and maintain good relationships between their employees and customers. Constant and continuous updates of customer information is key to proper knowledge management and a customer-oriented approach that will lead to employee and customer satisfaction. The findings from this study provide the required scientific evidence to support the aforementioned practical implications. This study provides insights of theoretical and practical relevance for a customer-oriented approach that drives job satisfaction and employee retention. Therefore, call centers can reap the positive benefits of long-term relationships and reduced costs of operations from creating the required customer-centric environment. This will encourage employees to engage customers in a productive and profitable manner.

This study suggests relevant operational alternatives to call centers whose current concerns include cost reduction and loss of intellectual property due to employee turnover. This study offers call center managers relevant options for achieving employee job satisfaction and a reduction in job turnover without resorting to expensive strategies like salary increases. Taking a relational intrinsic perspective that considers the typical dynamics in the African context, this study challenges managers in the explored call center setting to also consider training programs and activities that enhance employee empowerment in the drive to achieve a lower intention to quit. Drawing on organizational socialization theory, it is imperative to note the importance of adopting a learning orientation (e.g., Cooper-Thomas et al. 2014; Cooper-Thomas et al. 2012), as well as the significant role that insiders (e.g., supervisors) (e.g., Wanberg 2012; Feldman 2012) play in driving employee job satisfaction and employee commitment to the organization. Managers in this call center setting must assume responsibility and endorse appropriate initiatives for mitigating employee turnover intention. Additionally, call center managers must create a work environment that leverages the inherent benefits of knowledge management to achieve the desired job satisfaction and long-term relationships.

\section{Limitations and Directions for Future Research}

This study contributes to the customer relationship management and service marketing literature from the call center perspective. It examined the relationships between customer orientation, knowledge management, employee job satisfaction, and the intention to quit, and as a result, it also contributes to the internal marketing literature (e.g., Choi and Joung 2017; Kotler and Armstrong 2012).

Despite its contributions, this study has a few limitations. First, the convenience sampling approach was used in this study, and therefore, the extent to which the findings can be generalized across the call center population is limited. While this study focused on the two main independent variables of customer orientation and knowledge management, there is no denying the fact that a plethora of other factors exist that could be possible precursors of an employee's intention to quit, and these could be explored in future studies within the context of call centers. The finding that job satisfaction plays a mediating role in the relationship between customer orientation and intention-to-quit but not between knowledge management and intention-to-quit is surprising. Future research should aim to shed more light on the mediating influence of job satisfaction while using a larger sample of respondents. Future research could also validate the findings from this current study through quantitative or qualitative studies, or a combination of both. Unlike this current study, prior research found a positive association between customer orientation and employee job satisfaction in the New Zealand (e.g., Babakus et al. 2011) and Malaysia (e.g., Aliyu and Nyadzayo 2016). To validate this current study, as well as improve the overall knowledge in this theoretical domain, more illumination of that association is necessary.

To expand knowledge in this area, future research that takes a comparative approach from the point of service types, marketing types, and geographical contexts is also necessary. Regarding the geographical context, there is a wide range of options that can be considered in future research. Core comparative settings may include Western versus non-Western, 
developed, frontier and emerging markets, Islamic, and non-Islamic cultural settings. This study focused on the South African context, a setting that may not completely share the same cultural and market features with other African countries. Therefore, future research could also seek to explore the antecedents of employees' intention to quit in other African countries.

In pursing the aforementioned research directions, future research should incorporate processes that address the convenience sampling limitation of this study. A single informant organization data collection approach was used in this study: questionnaires were e-mailed to a call center manager, who distributed the questionnaires to respondents in the call center. Contrary to the methodological literature, which suggests a common method bias threat in one-informant dispensation (e.g., Podsakoff et al. 2003), the statistical results found no common method bias in this study. However, a future research should aim to embrace a multiple call center informant approach.

Finally, contrary to conceptualization, this study found no support for the notion that knowledge management negatively associates with intention to quit. Instead, at a significance level of 0.10 , it seems to suggest that there may be a positive association between knowledge management and intention to quit. Future research should take a closer look at this relationship and illuminate clearly under which conditions their association may be negative or positive.

Author Contributions: Conceptualization, writing - review and editing, original draft preparation, C.G.I., methodology, A.P.O. and O.A.A.; formal analysis, A.P.O., O.A.A., and C.E.-E.; writing-review, C.E.-E.; data collection, A.O.J.; literature development, T.B.M. All authors have read and agreed to the published version of the manuscript.

Funding: This research received no external funding.

Institutional Review Board Statement: The study was conducted according to the guidelines of the Faculty's Research Committee.

Informed Consent Statement: Informed consent was obtained from all subjects involved in the study.

Data Availability Statement: Not applicable.

Conflicts of Interest: The authors declare no conflict of interest.

\section{References}

Abdullateef, Aliyu Olayemi, Sany Sanuri Mohd Muktar, Rushami Zien Yusoff, and Intan Shafinaz Binti Ahmad. 2014. Effects of Customer Relationship Management Strategy on Call Centre's Employee Intention to Quit: Evidence from Malaysia Call Centers. Procedia-Social and Behavioural Sciences 130: 305-15. [CrossRef]

Aladwan, Khaled, Ramudu Bhanugopan, and Alan FishAladwan. 2013. Why do employees jump ship? Examining intent to quit employment in a non-western cultural context. Employee Relations 35: 408-22.

Alavi, Maryam, and Dorothy E. Leidner. 2001. Knowledge management and knowledge management systems: Conceptual foundations and research issues. MIS Quarterly 25: 107-36. [CrossRef]

Aliyu, Olayemi Abdullateef, and Munyaradzi Wellington Nyadzayo. 2016. Reducing employee turnover intention: A customer relationship management perspective. Journal of Strategic Marketing 26: 241-57. [CrossRef]

Antwerpen, Sumei van. 2016. Pivotal Role of Call Centre Managers from an Outsourced Telecommunications Company: A Case in Gauteng, South Africa. Journal of Communication 7: 197-207. [CrossRef]

Ashforth, Blake E., David M. Sluss, and Alan M. Saks. 2007. Socialization tactics, proactive behaviour, and newcomer learning: Integrating socialization models. Journal of Vocational Behaviour 70: 447-62.

Auh, Seigyoung, Bulent Menguc, Stavroula Spyropoulou, and Fatima Wang. 2016. Service employee burnout and engagement: The moderating role of power distance orientation. Journal of the Academy of Marketing Science 44: 726-45. [CrossRef]

Babakus, Emin, Ugur Yavas, and Nicholas J. Ashill. 2011. Service worker burnout and turnover intentions: Roles of person-job-fit, servant leadership, and customer orientation. Services Marketing Quarterly 32: 17-31.

Batt, Rosemary, and Mallika Banerjee. 2012. The scope and trajectory of strategic HR research: Evidence from American and British journals. The International Journal of Human Resource Management 23: 1739-62. [CrossRef]

Becton, Bret, Jon Carr, Kevin Mossholder, and Walker Jack. 2017. Differential effects of task performance, organizational citizenship behaviour, and job complexity on voluntary turnover. Journal of Business and Psychology 32: 495-508.

Belk, Russell W. 2013. Extended self in a digital world. Journal of Consumer Research 40: 477-500. [CrossRef] 
Bhaskar, A. Uday, and Bijaya Mishra. 2017. Exploring relationship between learning organizations dimensions and organizational performance. International Journal of Emerging Markets 12: 593-609. [CrossRef]

Bilau, Ade Abdulquadri, Akintunde Ajagbe, Anthony Babatunde Sholanke, and Tolani Abdulrahman Sani. 2015. Impact of employee turnover in small and medium construction firms: A literature review. International Journal of Engineering Research E Technology (IJERT) 4: 977-84.

Blocker, Christopher P., Daniel J. Flint, Matthew B. Myers, and Stanley F. Slater. 2011. Proactive customer orientation and its role for creating customer value in global markets. Journal of the Academy of Marketing Science 39: 216-33.

Bolisani, Ettore, and Constantin Bratianu. 2018. The elusive definition of knowledge. In Emergent Knowledge Strategies: Strategic Thinking in knowledge Management. Edited by Ettore Bolisani and Constantin Bratianu. Cham: Springer International Publishing, pp. 1-22. [CrossRef]

Bush, Tony. 2012. Authenticity in research: Reliability, validity and triangulation. In Research Methods in Educational Leadership and Management. Edited by Ann R. J. Briggs, Marianne Coleman and Marlene Morrison. London: Sage Publications Limited, chp. 6.

Byrne, Barbara M. 2010. Structural Equation Modeling with AMOS; Basic Concepts, Application and Programming, 2nd ed. New York: Routledge Taylor and Francis Group.

Central Intelligence Agency. 2019. The World Factbook. Available online: https://www.cia.gov/library/publications/the-worldfactbook/index.html (accessed on 16 February 2020).

Chan, Su Hui, Shan Yee Chok, Siew Yen Lae, An Chie Lam, and Chia Yi Lee. 2017. The Impact of Perceived Organizational Support, Job Satisfaction, Leader-Member Exchange (LMX) and Work-Life Balance on Employee's Turnover Intention in Manufacturing Industry. Doctoral dissertation, UTARA, Sintok, Malaysia.

Chen, Ching-Fu, and DungChun Tsai. 2007. How destination image and evaluative factors affect behavioural intentions? Tourism Management 28: 1115-22. [CrossRef]

Chen, Pei, Paul Sparrow, and Cary Cooper. 2016. The relationship between person-organization fit and job satisfaction. Journal of Managerial Psychology 31: 946-59.

Cheng, Cindy, Timothy Bartram, Leila Karimi, and Sandra Leggat. 2016. Transformational leadership and social identity as predictors of team climate, perceived quality of care, burnout and turnover intention among nurses. Personnel Review 45: 1200-16.

Chicu, Dorina, Gerard Ryan, and Valverde Mirela. 2016. Determinants of customer satisfaction in call centres. European Accounting and Management Review 2: 20-41.

Choi, Chang Hwan, Taegoo Terry Kim, Gyehee Lee, and Seung Kon Lee. 2014. Testing the stressor-strain-outcome model of social stressors in predicting emotional exhaustion, customer orientation and service recovery performance. International Journal of Hospitality Management 36: 272-85. [CrossRef]

Choi, Eun-Kyong, and Hyun-Woo Joung. 2017. Employee job satisfaction and customer-oriented behaviour: A study of frontline employees in the foodservice industry. Journal of Human Resources in Hospitality \& Tourism 16: 235-51.

Chughtai, Aamir Ali, and Finian Buckley. 2011. Work engagement: Antecedents, the mediating role of learning goal orientation and job performance. Career Development International 16: 684-705. [CrossRef]

Cohen, Aaron, and Aya Veled-Hecht. 2010. The relationship between organizational socialization and commitment in the workplace among employees in long-term nursing care facilities. Personnel Review 39: 537-56. [CrossRef]

Contractor, Farok. 2013. Punching above their weight: The sources of competitive advantage for emerging market multinationals. International Journal of Emerging Markets 8: 304-28. [CrossRef]

Conway, James M., and Allen I. Huffcutt. 2003. A review and evaluation of exploratory factor analysis practices in organizational research. Organizational Research Methods 6: 147-68. [CrossRef]

Cooper-Thomas, Helena, Neil Anderson, and Melanie Cash. 2012. Investigating organisational socialisation: A fresh look at newcomer adjustment strategies. Personnel Review 41: 41-55.

Cooper-Thomas, Helena, Nicole Paterson, Matthias Stadler, and Alan Saks. 2014. The relative importance of proactive behaviours and outcomes for predicting newcomer learning, well-being and work engagement. Journal of Vocational Behavior 84: 318-31.

Crossley, Craig, Rebecca Bennett, Steve Jex, and Jennifer Burnfield. 2007. Development of a global measure of job embeddedness and integration into a traditional model of voluntary turnover. Management Department Faculty Publications 34: 1031-42. [CrossRef]

Dabholkar, Pratibha, David Shepherd, and Dayle Thorpe. 2000. A comprehensive framework for service quality: An investigation of critical conceptual and measurement issues through a longitudinal study. Journal of Retailing 76: 139-73. [CrossRef]

De Winne, Sophie, Elise Marescaux, Luc Sels, Ilke Van Beveren, and Stijn Vanormelingen. 2018. The impact of employee turnover and turnover volatility on labour productivity: A flexible non-linear approach. The International Journal of Human Resource Management 30: 3049-79.

Dean, Alison M. 2007. The impact of the customer orientation of call centre employees on customers' affective commitment and loyalty. Journal of Service Research 10: 161-73.

Dhanpat, Nelesh, Faith Modau, Phokela Lugisani, Rethabile Mabojane, and Mbail Phiri. 2018. Exploring employee retention and intention to leave within a call centre. SA Journal of Human Resource Management 16: 1-13.

Dhar, Rajib Lochan. 2015. Service quality and the training of employees: The mediating role of organizational commitment. Tourism Management 46: 419-30.

Donate, Mario J., and Jesús D. Sánchez de Pablo. 2015. The role of knowledge-oriented leadership in knowledge management practices and innovation. Journal of Business Research 68: 360-70. 
Donavan, Todd, Tom Brown, and John Mowen. 2004. Internal benefits of service-worker customer orientation: Job satisfaction, commitment, and organizational citizenship behaviours. Journal of Marketing 68: 128-46.

Ertürk, Alper, and Levent Vurgun. 2015. Retention of IT professionals: Examining the influence of empowerment, social exchange, and trust. Journal of Business Research 68: 34-46. [CrossRef]

Feldman, Daniel C. 2012. The Impact of Socializing Newcomers on Insiders. In The Oxford Handbook of Organisational Socialisation. Edited by Wanberg Connie. New York: Oxford University Press.

Feyerabend, Rich, Ann M. Herd, and Namok Choi. 2018. Job satisfaction and turnover intentions among Indian call center agents: Exploring the role of emotional intelligence. The Psychologist-Manager Journal 21: 106.

Field, Andy P. 2009. Discovering Statistics Using SPSS for Windows: Advanced Techniques for the Beginner; Sage. Available online: https:/ /books.google.co.za/books?hl=en\&lr=\&id=T1empBxTFwYC\&oi=fnd\&pg=PA215\&dq=The+Impact+of +Socializing+ Newcomers+on+Insiders.+In+The+Oxford+Handbook+of+Organisational+Socialisation.+Edited+by+Wanberg, +C.+R\& ots=YPTsPNn9gZ\&sig=Zrs_NjVc0ihDoxlBQi99d8q4zY8\&redir_esc=y\#v=onepage\&q=The $\% 20 I m p a c t \% 200 f \% 20$ Socializing $\%$ 20Newcomers\%20on\%20Insiders. \%20In\%20The\%20Oxford\%20Handbook\%20of\%20Organisational\%20Socialisation. \%2 0Edited\%20by\%20Wanberg\%2C\%20C.\%20R\&f=false (accessed on 10 January 2021).

Fornell, Claes, and David F. Larcker. 1981. Structural equation models with unobservable variables and measurement error: Algebra and statistics. Journal of Marketing Research 18: 39-50. [CrossRef]

Garrido-Moreno, Aurora, Antonio Padilla-Meléndez, and Ana Rosa Del Águila-Obra. 2010. Exploring the importance of knowledge management for CRM success. International Journal of Social, Behavioural, Educational, Economic, Business and Industrial Engineering 4: 629-33.

Gazzoli, Gabriel, Murat Hancer, and BeomCheol Peter Kim. 2013. Explaining why employee-customer orientation influences customers' perceptions of the service encounter. Journal of Service Management 24: 382-400.

Gbadamosi, Ayantunji. 2016. Consumer behaviour in developing nations. In The Handbook of Research on Consumerism and Buying Behaviour in Developing Nations. IGI Global Book Series Advances in Marketing, Customer Relationship Management, and EServices (AMCRMES). Pennsylvania: IGI-Global Hershey.

Gianfranco, Walsh. 2011. Unfriendly customers as a social stressor: An indirect antecedent of service employees' quitting intention. European Management Journal 29: 67-78.

Greenawald, Erin. 2019. Worried about your Employee Turnover? See How It Stacks Up. Available online: https: / / www.reflektive. $\mathrm{com} / \mathrm{blog}$ / average-retention-industry / (accessed on 18 June 2019).

Hagos, Sirak, Michal Izak, and Jonathan M. Scott. 2019. Objective institutionalized barriers and subjective performance factors of new migrant entrepreneurs. International Journal of Entrepreneurial Behaviour E Research 25: 842-58.

Hair, Joe F., Jr., Michael Page, and Niek Brunsveld. 2019. Essentials of Business Research Methods. Abingdon: Routledge.

Hair, Joseph F., William C. Black, Barry J. Babin, and Rolph E. Anderson. 2010. Multivariate Data Analysis—A Global Perspective, 7th ed. Upper Saddle River: Pearson Education.

Hennig-Thurau, Thorsten. 2004. Customer orientation of service employees: Its impact on customer satisfaction, commitment, and retention. International Journal of Service Industry Management 15: 460-78. [CrossRef]

$\mathrm{Hu}$, Li-tze, and Peter M. Bentler. 1999. Cutoff criteria for fit indexes in covariance structure analysis: Conventional criteria versus new alternatives. Structural Equation Modeling: A Multidisciplinary Journal 6: 1-55. [CrossRef]

Ibrahim, Maha, and Saoud Al Falasi. 2014. Employee loyalty and engagement in UAE public sector. Employee Relations 36: 562-82. [CrossRef]

Ibrahim, Musa Umar. 2015. The development of knowledge management and innovation management in a management consulting organisation in the UK. Ph.D. thesis, Birmingham City University, Birmingham, UK.

Iwu, Chux Gervase, and Wilfred Isioma Ukpere. 2013. Revisiting incentives and job satisfaction of Nigerian bank employees. African Journal of Business Management 6: 11536-48.

Izogo, Ernest Emeka. 2016. Structural equation test of relationship quality: Repurchase intention-Willingness to recommend framework in retail banking. International Journal of Emerging Markets 11: 374-94. [CrossRef]

Jöreskog, Karl G. 1971. Statistical analysis of sets of congeneric tests. Psychometrika 36: 109-33. [CrossRef]

Kammeyer-Mueller, John D., Connie R. Wanberg, Theresa M. Glomb, and Dennis Ahlburg. 2005. Turnover processes in a temporal context: It's about time. Journal of Applied Psychology 90: 644-58. [CrossRef] [PubMed]

Kantsperger, Roland, and Werner H. Kunz. 2005. Managing overall service quality in customer care centres. International Journal of Service Industry Management 16: 135-51. [CrossRef]

Kennedy, Ann-Marie, and Gene R. Laczniak. 2016. Conceptualisations of the consumer in marketing thought. European Journal of Marketing 50: 166-88. [CrossRef]

Khodakarami, Farnoosh, and Yolande E. Chan. 2014. Exploring the role of customer relationship management (CRM) systems in customer knowledge creation. Information \& Management 51: 27-42.

Kianto, Aino, Mika Vanhala, and Pia Heilmann. 2016. The impact of knowledge management on job satisfaction. Journal of Knowledge Management 20: 621-36. [CrossRef]

Kotler, Philip, and Gary Armstrong. 2012. Principles of Marketing, 12th ed. Englewood Cliffs: Prentice Hall.

Kundu, Subhash C., Archana Mor, Jahanvi Bansal, and Sandeep Kumar. 2019. Diversity-focused HR practices and perceived firm performance: Mediating role of procedural justice. Journal of Asia Business Studies 13: 214-39. [CrossRef] 
Lapointe, Émilie, and Christian Vandenberghe. 2017. Supervisory mentoring and employee affective commitment and turnover: The critical role of contextual factors. Journal of Vocational Behavior 98: 98-107. [CrossRef]

Leedy, Paul D., and Jeane Ellis Ormrod. 2014. Practical Research: Planning and Design, 10th ed. Upper Saddle River: Pearson Education, Inc.

LeRouge, Cynthia, Anthony Nelson, and J. Ellis Blanton. 2006. The impact of role stress fit and self-esteem on the job attitudes of IT professionals. Information \& Management 43: 928-38.

Leung, Doris Y. P., and Wincy W. S. Lee. 2006. Predicting intention to quit among Chinese teachers: Differential predictability of the components of burnout. Anxiety, Stress \& Coping 19: 129-41.

Lussier, Bruno, and Nathaniel N. Hartmann. 2017. How psychological resourcefulness increases salesperson's sales performance and the satisfaction of their customers: Exploring the mediating role of customer-oriented behaviours. Industrial Marketing Management 62: 160-70. [CrossRef]

Lussier, Bruno, and Zachary R. Hall. 2018. Cooperation in B2B relationships: Factors that influence customers' perceptions of salesperson cooperation. Industrial Marketing Management 69: 209-20. [CrossRef]

Lynch, Patrick D., Robert Eisenberger, and Stephen Armeli. 1999. Perceived organizational support: Inferior versus superior performance by wary employees. Journal of Applied Psychology 84: 467-83. [CrossRef]

McNally, Regina C. 2007. An exploration of call centre agents' CRM software use, customer orientation and job performance in the customer relationship maintenance phase. Journal of Financial Services Marketing 12: 169-84. [CrossRef]

Miller, Michael B. 1995. Coefficient alpha: A basic introduction from the perspectives of classical test theory and structural equation modeling. Structural Equation Modeling 2: 255-73. [CrossRef]

Molino, Monica, Federica Emanuel, Margherita Zito, Chiara Ghislieri, Lara Colombo, and Claudio G. Cortese. 2016. Inbound call centers and emotional dissonance in the job demands-resources model. Frontiers in Psychology 7: 1-13. [CrossRef]

Molm, Linda D., Nobuyuki Takahashi, and Gretchen Peterson. 2000. Risk and trust in social exchange: An experimental test of a classical proposition. American Journal of Sociology 105: 1396-27. [CrossRef]

Morgan Stanley Capital International (MSCI). 2019. Emerging Markets Index. Emerging Market Countries. Available online: https:/ / www.thebalance.com/msci-index-what-is-it-and-what-does-it-measure-3305948 (accessed on 15 February 2020).

Morgan Stanley Capital International (MSCI). 2020. Emerging Markets Report. Available online: https:// de.wikipedia.org/wiki/ MSCI_Emerging_Markets (accessed on 15 February 2020).

Mullins, Ryan R., Michael Ahearne, Son K. Lam, Zachary R. Hall, and Jeffrey P. Boichuk. 2014. Know your customer: How salesperson perceptions of customer relationship quality form and influence account profitability. Journal of Marketing 78: 38-58. [CrossRef]

Mwendwa, Lucy, and Amos K. Gitonga. 2017. Factors influencing call centre agent attrition: A case of Kenya Power call centre. International Academic Journal of Information Sciences and Project Management 2: 415-34.

Mwilu, Joseph Mutune. 2016. Factors Influencing Employee Turnover in the Hotel Industry in Machakos Town, Machakos County. Doctoral dissertation, South Eastern Kenya University, Kitui County, Kenya.

Napathorn, Chaturong. 2018. Contextual influences on HRM practices in social enterprises: The case of Thailand. International Journal of Emerging Markets 13: 1969-2000.

Narver, John C., and Stanley F. Slater. 1990. The effect of a market orientation on business profitability. Journal of Marketing 54: 20-35. [CrossRef]

Nawaz, Muhammad, and Faizuniah Pangil. 2016. The relationship between human resource development factors, career growth and turnover intention: The mediating role of organizational commitment. Management Science Letters 6: 157-76.

Nunnally, Jum C., and Ira H. Bernstein. 1994. Psychometric Theory. New York: McGraw-Hill.

Opute, Abdullah Promise. 2014. Cross-Functional Bridge in Dyadic Relationship: Conflict Management and Performance Implications. Team Performance Management 20: 121-47. [CrossRef]

Opute, Abdullah Promise. 2017. Exploring personality, identity and self-concept among young customers. In Young Consumer Behaviour. New York: Routledge (Taylor and Francis) Publications.

Opute, Abdullah Promise. 2020a. Teamwork and Customer Service. In Customer Service Management: A Strategic and Operational Perspective. Milton Park: Taylor and Francis, chp. 14.

Opute, Abdullah Promise. 2020b. Small and Medium Enterprises Marketing: Innovation and Sustainable Economic Growth Perspective. In Entrepreneurship Marketing: Principles and Practice of SME Marketing. Milton Park: Routledge Publishers.

Opute, Abdullah P., and Nnamdi Madichie. 2017. Accounting-Marketing Integration Dimensions and antecedents: Insights from a Frontier Market. Journal of Business and Industrial Marketing 32: 1144-58. [CrossRef]

Pandey, Arti, and Peerayuth Charoensukmongkol. 2019. Contribution of cultural intelligence to adaptive selling and customer-oriented selling of salespeople at international trade shows: Does cultural similarity matter? Journal of Asia Business Studies 13: 79-96. [CrossRef]

Park, Cheol, Jongkun Jun, Thaemin Lee, and Heejung Lee. 2018. Customer orientation or employee orientation: Which matters more? The moderating role of firm size. Journal of Business $\mathcal{E}$ Industrial Marketing. [CrossRef]

Podsakoff, Philip, Scott MacKenzie, Jeong-Yeon Lee, and Nathan Podsakoff. 2003. Common method biases in behavioral research: A critical review of the literature and recommended remedies. Journal ofApplied Psychology 88: 879-903. [CrossRef]

Politis, John. 2001. The relationship of various leadership styles to knowledge management. Leadership E Organization Development Journal 22: 354-64. 
Poon, Lee-Anne, and Lubabalo Dyantyi. 2004. Contact Centre Industry Loses Millions of Working Days a Year through Agent Absenteeism. Findings from the Merchants Global Contact Centre Benchmarking Report 2003. Available online: https://www. itweb.co.za/content/O2rQGMAp5Yx7d1ea (accessed on 14 June 2019).

Pradhan, Sajeet, Aman Srivastava, and Lalatendu Kesari Jena. 2019. Abusive supervision and intention to quit: Exploring multimediational approaches. Personnel Review. [CrossRef]

Richard, M. Royal. 1986. The Effect of Sample Size on the Meaning of Significance Tests. The American Statistician 40: $313-15$.

Sadeghi, Abdolreza, and Fereshteh Mostafavi Rad. 2018. The role of knowledge-oriented leadership in knowledge management and innovation. Management Science Letters 8: 151-60.

Saunders, Mark, Philip Lewis, and Adrian Thornhill. 2012. Research Methods for Business Students, 6th ed. Upper Saddle River: Pearson Education Limited.

Sims, Randi L., Cynthia P. Ruppel, and Peter Zeidler. 2016. Work strain, job satisfaction, and intention to quit: The moderating effect of long-term orientation. International Journal of Stress Management 23: 23. [CrossRef]

Sin, Leo Y. M., Alan C. B. Tse, and Frederick H. K. Yim. 2005. CRM: Conceptualization and scale development. European Journal of Marketing 39: 1264-90. [CrossRef]

Stock, Ruth Maria. 2016. Understanding the relationship between frontline employee born-out and customer orientation. Journal of Business Research 69: 4259-68.

Strandberg, Christer, and Rolf Dalin. 2010. The role of strategic context, operational requirements, and work design in in-house call centres in the financial sector. Managing Service Quality: An International Journal 20: 544-64.

Suliman, Abubakr M., and Hanan Al Obaidli. 2011. Organizational climate and turnover in Islamic banking in the UAE. International Journal of Islamic and Middle Eastern Finance and Management 4: 308-24. [CrossRef]

Walsh, Gianfranco, and Boris Bartikowski. 2013. Employee emotional labour and quitting intentions: Moderating effects of gender and age. European Journal of Marketing 47: 1213-37.

Wanberg, Connie, ed. 2012. The Oxford Handbook of Organizational Socialization. Oxford: Oxford University Press.

Wasserstein, Ronald L., and Nicole A. Lazar. 2016. The ASA Statement on p-Values: Context, Process, and Purpose. The American Statistician 70: 129-33. [CrossRef]

Wayde, R. Pandy, and Christian M. Rogerson. 2014. South Africa's call centre industry: The emerging challenges of a growing destination in the global South. Mediterranean Journal of Social Sciences 5: 208-17. [CrossRef]

Witt, L. Alan, and John W. Wilson. 1990. Income sufficiency as a predictor of job satisfaction and organizational commitment: Dispositional differences. Journal of Social Psychology 130: 267-68. [CrossRef]

Wong, Kuan Yew. 2005. Critical success factors for implementing knowledge management in small and medium enterprises. Industrial Management \& Data Systems 105: 261-79.

Yim, Frederick Hong-kit, Rolph E. Anderson, and Srinivasan Swaminathan. 2005. Customer relationship management: Its dimensions and effect on customer outcomes. Journal of Personal Selling and Sales Management 24: 263-78.

Yue, Cen April, Linjuan Rita Men, and Mary Ann Ferguson. 2019. Bridging transformational leadership, transparent communication, and employee openness to change: The mediating role of trust. Public Relations Review. [CrossRef]

Zack, Michael, James McKeen, and Satyendra Singh. 2009. Knowledge management and organizational performance: An exploratory analysis. Journal of Knowledge Management 13: 392-409.

Zheng, Wei, Baiyin Yang, and Gary N. McLean. 2010. Linking organizational culture, structure, strategy, and organizational effectiveness: Mediating role of knowledge management. Journal of Business Research 63: 763-71. [CrossRef]

Zurnamer, Siobhan. 2019. Why Do Call Centres Have the Worst Attrition Rates in South Africa? Available online: https://blog.giraffe. co.za/gwhy-do-call-centres-have-the-worst-attrition-rates-in-south-africa (accessed on 16 June 2019). 